\title{
AMCoR
}

Asahikawa Medical College Repository http://amcor. asahikawa-med. ac. jp/

Neuroscience (2007) 148(1):175-187.

Neuropsin promotes oligodendrocyte death, demyelination and axonal degeneration after spinal cord injury.

Terayama R, Bando Y, Murakami K, Kato K, Kishibe M, Yoshida S. 


\section{Neuropsin promotes oligodendrocyte death, demyelination and axonal degeneration after spinal cord injury}

Ryuji Terayama ${ }^{1,3}$, Yoshio Bando ${ }^{1}$, Koichi Murakami ${ }^{1}$, Kohei Kato ${ }^{1}$, Mari Kishibe ${ }^{1,2}$ and Shigetaka Yoshida ${ }^{1}$

${ }^{1}$ Department of Functional Anatomy and Neuroscience, ${ }^{2}$ Department of Dermatology, Asahikawa Medical College, Asahikawa 078-8510, Japan

${ }^{3}$ Department of Oral Function and Anatomy, Okayama University Graduate School of Medicine, Dentistry and Pharmaceutical Sciences, Okayama 700-8525, Japan

Address correspondence to:

Ryuji Terayama

Department of Oral Function and Anatomy

Okayama University Graduate School of Medicine, Dentistry and Pharmaceutical Sciences

2-5-1 Shikata-cho, Okayama 700-8525, Japan

Phone: +81 862356637

Fax: $\quad+81862356639$ 
E-mail: ryujit@md.okayama-u.ac.jp

Section: Molecular

Section Editor: Dr. Werner Sieghart 
Abbreviations: SCI, spinal cord injury; DIG, digoxigenin; APC, adenomatus polyposis coli; MBP, myelin basic protein; TUNEL, TdT-mediated dUTP-fluorescein nick end labeling 


\section{Abstract}

Previous studies indicated that the expression of neuropsin, a serine protease, is induced in mature oligodendrocytes after injury to the central nervous system (CNS). The pathophysiology of spinal cord injury (SCI) involves primary and secondary mechanisms, the latter contributing further to permanent losses of function. To explore the role of neuropsin after SCI, histochemical and behavioral analyses were performed in wild-type (WT) and neuropsin-deficient (neuropsin ${ }^{-/}$) mice using a crush injury model, a well-characterized and consistently reproducible model of SCI. In situ hybridization revealed that neuropsin mRNA expression was induced in the spinal cord white matter from WT mice after crush SCI, peaking at day 4. Neuropsin ${ }^{-/-}$mice showed attenuated demyelination, oligodendrocyte death, and axonal damage after SCI. Although axonal degeneration in the corticospinal tract was obvious caudal to the lesion site in both strains of mice after SCI, the number of surviving nerve fibers caudal to the lesion was significantly larger in neuropsin ${ }^{--}$mice than WT mice. Behavioral analysis revealed that the recovery at days 10-42 was significantly improved in neuropsin ${ }^{-/-}$mice compared to WT mice in spite of the severe initial hindlimb impairments due to SCI in both strains. These observations suggest that neuropsin is involved in the secondary phase of the pathogenesis of SCI mediated by demyelination, oligodendrocyte death, and axonal degeneration. 
Keywords: serine protease; secondary injury; in situ hybridization;

immunofluorescence labeling; tract tracing; behavior 


\section{Introduction}

The pathophysiology of spinal cord injury (SCI) involves primary and secondary mechanisms. Following an initial impact after SCI, there is a delayed and progressive period of secondary damage that contributes to the loss of sensory and voluntary motor function (Lu et al., 2000; Park et al., 2004). This secondary phase of injury includes ischemia, inflammation and glutamate excitotoxicity, together with neuronal and glial cell death. These processes are mediated by changes in the constitution of a variety of extracellular matrix components (Sanes, 1983, 1989), growth factors (Mocchetti and Wrathall, 1995), and proteolytic cascades (Krystosek and Seeds, 1981; Monard, 1988; Seeds et al., 1990). Several groups have now demonstrated that oligodendrocyte death and subsequent demyelination are involved in the pathology after SCI ( $\mathrm{Lu}$ et al., 2000; Blight, 2002; Dong et al., 2003; Park et al., 2004). Oligodendrocyte loss and demyelination result in inadequate nerve conduction and the appearance of neurological deficits, which are potential targets for improving function after SCI even in the absence of axonal regeneration.

Since oligodendrocytes have protease activity which might contribute to the pathology after SCI (Berlet et al., 1984), the identification and characterization of key enzymatic players may suggest new therapeutic targets to reduce further damage and promote remyelination. Kallikreins are serine proteases that comprise a recently 
identified large and closely related 15-member family in humans. Mice are reported to carry up to 37 kallikrein genes including genes homologous to newly identified human kallikreins. These kallikreins serve a variety of physiological functions including regulation of blood pressure, neuronal health, and the inflammatory response (Borgono and Diamandis, 2004; Borgono et al., 2004; Diamandis et al., 2004). Neuropsin is a kallikrein-like serine protease whose mRNA is constitutively expressed specifically in the neurons of the limbic system of the adult mouse brain (Chen et al., 1995; Yoshida and Shiosaka, 1999; Shiosaka and Yoshida, 2000). KLK8 was assigned as the gene for the human analogue (Yoshida et al., 1998; Yousef et al., 2003). A biochemical analysis of recombinant and native neuropsin suggested that it is an extracellular trypsin-type protease with a relatively narrow spectrum of substrates (Shimizu et al., 1998). Our previous experiments showed that traumatic, excitotoxic and immunological injury induced expression of neuropsin mRNA in the area surrounding the lesion in the CNS (Tomizawa et al., 1999; Terayama et al., 2004; Terayama et al., 2005a). Combined in situ hybridization and immunohistochemistry revealed that most of the cells expressing neuropsin mRNA were mature oligodendrocytes (Terayama et al., 2004).

Although upregulation of neuropsin expression after injury to the CNS has been reported, the functional roles of neuropsin are not fully characterized. We therefore examined changes in the expression of neuropsin in wild-type (WT) mice and assessed the pathophysiological response in neuropsin-deficient (neuropsin ${ }^{-/}$) mice. We used a 
crush injury model, a well-characterized and consistently reproducible model of SCI that allows evaluation of both cell biology and behavior (Inman et al., 2002; Faulkner et al., 2004) to examine the differences between WT and neuropsin ${ }^{-/-}$mice in pathological hallmarks and functional outcome after SCI. 


\section{Experimental procedures}

\section{Mice}

Neuropsin $^{-/-}$mice were derived from heterozygous (neuropsin ${ }^{+/}$) mice after backcrossing with C57BL/6 mice for at least 10 generations. Complete loss of neuropsin mRNA was confirmed with a cDNA probe covering exon 2-4 including the histidine residue essential for proteolytic activity (Hirata et al., 2001; Kirihara et al., 2003). Adult (6- to 8-week-old) mice were used in all experiments (Table 1). Mice were bred in-house (Division of Laboratory Animal Resources at Asahikawa Medical College), controlled for temperature $\left(20^{\circ} \mathrm{C}\right)$, and maintained with a daily light period of $12 \mathrm{hr}$ Paralyzed mice were given easy access to food and hand watered at least twice daily. All procedures described herein were approved by the Animal Care Committee of Asahikawa Medical College, in accordance with the National Institutes of Health Guide for the Care and Use of Laboratory Animals (NIH Publications No. 80-23), revised 1996. Every attempt was made to minimize the number of animals used and to reduce their suffering at all stages of the study.

\section{Spinal cord injury}

Mice were anesthetized with an intraperitoneal injection of pentobarbital sodium

(Nembutal, 40-50 mg/kg). Under a dissecting microscope, a laminectomy at the T10 
level was performed to injure the spinal cord at L1 level with number 5 Dumont forceps ground down to a tip width of $0.5 \mathrm{~mm}$. The forceps we used in this report were modified with a spacer so that at maximal closure a $0.6 \mathrm{~mm}$ space remained to make incomplete lesion (Faulkner et al., 2004). The spinal cord was compressed with the forceps laterally from both sides for $10 \mathrm{sec}$ (Fig. 1A, B). After the wound was sutured, animals were allowed to survive for 1-42 days.

\section{Tissue preparation}

At days $0,1,4,7$ and 14 post-injury, animals ( $n=3-5$ per strain at each time point; Table 1) were re-anesthetized and perfused transcardially with saline followed by $4 \%$ paraformaldehyde in 0.1 M phosphate buffer ( $\mathrm{PB}, \mathrm{pH}$ 7.4). The spinal cord including the lesion was removed, postfixed overnight in the same fixative, and then immersed in 30\% sucrose in 0.1 M PB for 1-2 days. The spinal cord was then frozen in powdered dry ice, embedded in Tissue-Tek (Miles, Elkhart, IN, USA) optimal cutting temperature compound, and stored at $-80{ }^{\circ} \mathrm{C}$ prior to use. Frozen $14 \mu \mathrm{m}$ transverse sections of the spinal cord were cut on a cryostat and mounted onto silane-coated slides. Sections were processed for detection of multiple markers to find the differences between WT and neuropsin ${ }^{-/-}$mice after SCI.

\section{In situ hybridization}


In situ hybridization was performed using a digoxigenin (DIG, Roche Molecular Biochemicals, Mannheim, Germany)-labeled cRNA probe for neuropsin and proteolipid protein (PLP) mRNA. The method used for in situ hybridization was described in previous papers (Yoshida et al., 1994; Chen et al., 1998; Terayama et al., 2004). In brief, slide-mounted sections were postfixed in $4 \%$ formaldehyde in $0.1 \mathrm{M} \mathrm{PB}$, and treated with $10 \mu \mathrm{g} / \mathrm{ml}$ of proteinase $\mathrm{K}$, followed by $0.25 \%$ acetic anhydrate in $0.1 \mathrm{M}$ triethanolamine ( $\mathrm{pH}$ 8.0) for $10 \mathrm{~min}$ at RT. The sections were dehydrated and defatted in graded alcohol solutions and chloroform, respectively and air-dried before application of the hybridization buffer at $55^{\circ} \mathrm{C}$ for $1 \mathrm{hr}$. Hybridization was performed overnight at $55{ }^{\circ} \mathrm{C}$ in a humidified chamber with hybridization buffer containing 10 ng/100 $\mu \mathrm{l}$ of the DIG-labeled cRNA probe (Terayama et al., 2004). The hybridized sections were washed in $4 \times$ standard saline citrate (SSC) buffer ( $\mathrm{pH} 7.4$ ) for $20 \mathrm{~min}$ and then in $50 \%$ formamide $/ 4 \times$ SSC buffer at $60{ }^{\circ} \mathrm{C}$ for $30 \mathrm{~min}$. After being treated with RNase A, sections were incubated with alkaline phosphatase (ALP)-anti-DIG antibody (Roche Molecular Biochemicals) at a dilution of 1:500. Sections were developed for $48 \mathrm{hr}$ in the dark with $10 \%$ polyvinyl alcohol containing $3.75 \mu \mathrm{l} / \mathrm{ml}$ of 5-bromo-4-chloro-3-indolyl phosphate (BCIP, Roche Molecular Biochemicals) and 5 $\mu \mathrm{l} / \mathrm{ml}$ of nitroblue tetrazolium (NBT, Roche Molecular Biochemicals). The specificity of the hybridization signal was verified by comparing adjacent sections hybridized with antisense and sense probes of comparable specific activity. In a given area (250 $\mu \mathrm{m} \times$ 
$180 \mu \mathrm{m})$, the number of PLP-positive cells in the white matter of five randomly selected sections within 400-600 $\mu \mathrm{m}$ rostral and caudal to the epicenter was counted at each survival time point. PLP-positive cells were defined as cells with dark blue staining in the cell body, regardless of staining intensity, but cells with very weak equivocal staining were considered negative. The data from three individual experiments were represented as the mean number of cells \pm SEM and used for statistical analysis (Student's $t$-test).

\section{Immunofluorescence labeling}

The sections were immersed in PBS containing 1\% Triton X-100 for $1 \mathrm{hr}$. Non-specific antibody binding was blocked with $3 \%$ normal goat serum in PBS containing 2\% BSA for $1 \mathrm{hr}$. Primary antibodies including anti-myelin basic protein (MBP, mouse monoclonal, Sternberger Monoclonal, Lutherville, MD, USA; 1:1,000), anti-activated caspase-3 (rabbit polyclonal, Cell Signaling Technology, Beverly, MA, USA; 1:200), and anti-adenomatus polyposis coli (APC, mouse monoclonal, Oncogene, Manhasset, NY, USA; 1:1,000) were applied for $24 \mathrm{hr}$ at RT. Alexa-488 and Alexa-594 (Molecular Probes, Eugene, OR, USA; 1:1,000)-conjugated secondary antibodies were used to visualize primary antibody binding. The primary antibody was omitted for negative controls.

For the image analysis, Lumina Vision software (Mitani Corp., Fukui, Japan) was 
used to measure the MBP-immunoreactive (IR) intensity of the spinal cord white matter within 400-600 $\mu \mathrm{m}$ rostral and caudal to the epicenter at days 0,4 and 14 after SCI. The IR intensity was defined as the mean light intensity per unit area of the whole white matter subtracted from background (immunonegative area) level in each section. Images of the spinal cord were captured, outlined the white matter and a numerical value of the mean light intensity per unit area was calculated. Fluorescence illumination was kept low to ensure that the camera output remained within the linear range, so the measured value of light intensity was proportional to fluorescence density. The data from five individual experiments were represented as the mean IR intensity \pm SEM and used for statistical analysis (Student's $t$-test). The number of double-labeled cells positive for caspase-3 and APC in three randomly selected sections within 400-600 $\mu \mathrm{m}$ rostral and caudal to the epicenter was counted at day 4 after SCI. The data from five individual experiments were represented as the mean number of cells \pm SEM.

\section{In situ detection of DNA fragmentation (TUNEL)}

Terminal deoxynucleotidyl transferase (TdT)-mediated deoxyuridine triphosphate (dUTP)-fluorescein nick end labeling (TUNEL) was performed for the detection of fragmented DNA. The sections were incubated in tailing buffer containing $0.1 \mathrm{mM}$ ATP, 0.05 mM fluorescein 12-dUTP and $25 \mathrm{U} / \mu \mathrm{l}$ terminal deoxynucleotidyl transferase

(Promega, Madison, WI, USA) for $60 \mathrm{~min}$ at $37{ }^{\circ} \mathrm{C}$. The sections were further 
processed for immunofluorescence labeling with mouse monoclonal anti-APC (Oncogene; 1:1,000) to identify oligodendrocytes. Alexa-594-conjugated goat anti-mouse IgG (Molecular Probes; 1:1,000) was used to visualize primary antibody binding. The number of double-labeled cells positive for TUNEL and APC in three randomly selected sections within 400-600 $\mu \mathrm{m}$ rostral and caudal to the epicenter was counted at each survival time point. The data from five individual experiments were represented as the mean number of cells \pm SEM and used for statistical analysis (Student's $t$-test).

\section{Histological analysis of tissue injury}

Histological analysis was also carried out on spinal cord specimens. Briefly, 10- $\mu \mathrm{m}$ thick horizontal sections of the lower thoracic and upper lumber spinal cord from WT and neuropsin ${ }^{-/-}$mice at day 14 after SCI ( $n=5$ in each strain; Table 1$)$ were stained with hematoxylin and eosin. Lesion areas from sections containing the central canal were outlined using Lumina Vision software according to commonly accepted qualitative criteria (Zhang et al., 1996; Faulkner et al., 2004); damaged tissue exhibited staining pallor and cellular disorder, and intact tissue contained cells with clear nuclei and regular distribution of cells. The lesion size was calculated using image analysis software (Lumina Vision) for statistical analysis (Student’s t-test). 


\section{Electron microscopy}

At day 14 post-injury, animals ( $n=3$ in each strain; Table 1) were transcardially perfused with $2 \%$ glutaraldehyde and $2 \%$ paraformaldehyde in $0.1 \mathrm{M}$ PB. The spinal cords were removed, fixed with $1 \%$ osmium tetroxide and embedded in Epon. Ultrathin sections were cut from the ventral funiculus within 400-600 $\mu \mathrm{m}$ rostral to the epicenter, stained with uranyl acetate and lead citrate and observed in the electron microscopy.

\section{Anterograde tract tracing with biotinylated dextran amine (BDA)}

To investigate the differences in axonal degeneration between WT and neuropsin ${ }^{-/-}$mice after SCI, five animals in each strain with or without SCI (Table 1) were gently injected with a $10 \%$ solution of BDA (MW 10,000; Molecular Probes) into the sensorimotor cortex using a $30 \mathrm{G}$ needle connected to a $1 \mu$ l Hamilton syringe (\#86200, Hamilton Company, Reno, NV, USA) at the day of SCI. Three injections (0.3 $\mu$ l each) were made at $1.0 \mathrm{~mm}$ lateral to the midline at $0.0,0.5$, and $1.0 \mathrm{~mm}$ posterior to the bregma, and at a depth of $0.5 \mathrm{~mm}$ from the cortical surface. The animals were perfused with 4\% paraformaldehyde in 0.1 M PB 14 days after the operation. After cryoprotection, frozen spinal cord sections were serially cut at $20 \mu \mathrm{m}$ in a horizontal plane and mounted onto silane-coated slides. Sections were washed in PBS with $0.3 \%$ hydrogen peroxide for $1 \mathrm{hr}$, and then incubated overnight with streptavidine-horseradish peroxidase 
(Vectastain Elite ABC Kit, Vector Laboratories, Burlingame, CA, USA; 1:200) and visualized with DAB. The number of CST fibers $1.0 \mathrm{~mm}$ rostral and caudal to the epicenter was counted in at least 5 sections within 100-300 $\mu$ m dorsal to the central canal. The data from five individual experiments were represented as the mean number of fibers per section and used for statistical analysis (Student’s $t$-test).

\section{Real-time quantitative PCR}

After postoperative periods of $0,1,4,7$, and 14 days, another group of WT mice $(n=$ 15; Table 1) were given a lethal dose of anesthetic (100 mg/kg), a laminectomy was performed to expose the spinal cord, and an approximately $4.0 \mathrm{~mm}$ rostrally-caudally oriented section of the spinal cord, centered on the lesion site, was quickly dissected. Total RNA was extracted using TRIzol reagent (Invitrogen Life Technologies, Carlsbad, CA, USA). The first strand cDNA was synthesized with AMV reverse transcriptase (Promega) at $42{ }^{\circ} \mathrm{C}$ for $1 \mathrm{hr}$. The cDNA was diluted a hundred-fold prior to PCR amplification. The LightCycler rapid thermal system (Roche Diagnostics, Penzberg, Germany) was used according to the manufacturer's instructions. Reactions were performed in a $20 \mu \mathrm{l}$ volume with $0.5 \mu \mathrm{M}$ primers and a $\mathrm{MgCl}_{2}$ concentration optimized between 2-5 mM. Deoxynucleotides, Taq DNA polymerase, and buffer were included in the LightCycler-DNA Master SYBR Green I mix (Roche Diagnostics). PCR was performed under the following conditions: initial denaturation for $10 \mathrm{~min}$ at $95^{\circ} \mathrm{C}$, and 
40 cycles of denaturation for $0 \mathrm{~s}$ at $95^{\circ} \mathrm{C}$, annealing for $5 \mathrm{~s}$ at $56-57^{\circ} \mathrm{C}$, and enzymatic chain extension for $10 \mathrm{~s}$ at $72^{\circ} \mathrm{C}$. Each PCR assay included a negative control consisting of $\mathrm{H}_{2} \mathrm{O}$ without any template DNA to monitor for possible contamination. To confirm amplification specificity, the PCR products from each primer pair were subjected to a melting curve analysis and subsequent agarose gel electrophoresis. The PCR primers were designed according to published sequences of neuropsin, CCCACTGCAAAAAACAGAAG (sense); TGTCAGCTCCATTGCTGCT (antisense). Glyceraldehyde phosphate dehydrogenase (GAPDH) mRNA was used as an internal control: CGGGAAGCCCATCACCATCA (sense); GAGGGGCCATCCACAGTCTT (antisense). All primers were synthesized by Genosys (Sigma, St Louis, MO, USA).

The quantified data were analyzed with the LightCycler analysis software. A serially diluted cDNA from control mouse spinal cord was used for standard. The level of each specific cDNA was quantified in the exponential phase of the PCR amplification and normalized with the level of GAPDH mRNA expression in each individual sample. The data from three individual experiments were used for statistical analysis (ANOVA with post hoc Fisher's PLSD test).

\section{Western Blot Analysis}

Three animals in each strain at days 0 and 4 were used for western blot analysis (Table

1). The spinal cords, centered on the lesion site were quickly dissected and washed 
with PBS. A section of the spinal cord was truncated to a length of approximately 4.0 mm. For caspase assay, spinal cords were homogenized in assay buffer (50 mM Tris-HCl, pH 7.4, 1 mM EDTA, and 10 mM EGTA), and then frozen immediately. After adding $10 \mu \mathrm{M}$ digitonin, the homogenate was incubated at $37{ }^{\circ} \mathrm{C}$ for $10 \mathrm{~min}$. The homogenate was clarified by centrifugation at 15,000 rpm for $10 \mathrm{~min}$. The clear supernatant fraction was used for immunoblotting. After the determination of the protein concentration (DC protein assay kit; Bio-Rad, Hercules, CA, USA), equal amounts of protein $(40 \mu \mathrm{g})$ from the spinal cords were loaded on each lane of a $15 \%$ polyacrylamide gel for sodium dodecyl sulfate-polyacrylamide gel electrophoresis (SDS-PAGE). After electrophoresis, proteins were transferred onto an Immobilon-P membrane (Millipore, Bedford, MA, USA). Immunoblotting was carried out using rabbit monoclonal anti-activated caspase-3 antibody (1:500; R \& D Systems, Minneapolis, MN, USA). The blots were incubated for $1 \mathrm{hr}$ at RT with ALP-conjugated secondary antibodies, developed in ALP buffer containing BCIP and NBT. Even loading was verified using mouse monoclonal anti-tubulin antibody (1:1,000; Sigma). Immunoblots were scanned for densitometric analysis (Scion National Institutes of Health Image 1.60). The level of activated caspase-3 expression was normalized with the level of tubulin expression in each individual sample. The raw data from three individual experiments were used for statistical analysis (Student's $t$-test). 


\section{Behavioral analysis}

WT and neuropsin ${ }^{-/-}$mice ( $n=8$ in each strain; Table 1 ) were evaluated using two behavioral tasks selected to assess hindlimb function at days 1, 4, 7, 10, 14, 21, 28, 35 and 42 post-injury.

Open field locomotor task. Mice were evaluated in an open field by the same one or two observers blinded to the experimental conditions and received a score for movement of each hindlimb using the Basso Beattie Bresnahan (BBB) motor rating scale (Basso et al., 1995). This is a 22-point scale (scores 0-21) that systemically details the hindlimb function of joint movement, stepping ability, the degree of fine control of co-ordinated stepping and trunk stability. Briefly, beginning 5 days prior to SCI, animals were acclimated in an open field arena for 5 min durations. On the day of SCI, all animals had a score of 21.

Rotorod. To assess balance and ability to co-ordinate stepping, animals were placed on a single-lane rotorod (Ugo Basile Biological Research Apparatus, Comerio-Varese, Italy) for three trials per session. The rotorod was set for constant acceleration from 3.0 to $30 \mathrm{rpm}$ over $300 \mathrm{sec}$, and the time taken in seconds for animals to fall. Each trial was scored individually and averaged for a final score per session. 


\section{Statistical analysis}

Three to five mice were included in each strain at each survival time point for quantification of RT-PCR, Western blot, and histological analyses. A total of 8 mice for each strain were included for behavioral studies. Differences between groups were compared by Student's t-test or ANOVA with post hoc Fisher's PLSD test. The criterion for statistical significance was $P<0.05$. 


\section{Results}

\section{Changes in the expression of neuropsin mRNA after injury to the spinal cord}

We first examined neuropsin mRNA expression in unlesioned and lesioned spinal cord of WT mice. The distribution of mRNA encoding neuropsin was determined by in situ hybridization. There was an increase in the expression of neuropsin mRNA after crush SCI (Fig. 1C-F). In untreated control animals, neuropsin mRNA was observed in a small number of cells in the gray but not white matter of the spinal cord (Fig. 1C). After SCI, neuropsin mRNA was induced in the white matter immediately adjacent to the lesion. This induction was observed at days 1-14 post-injury, peaking at day 4 (Fig. 1D, E). The quantitative RT-PCR analysis using a real time LightCycler system confirmed that the expression of mRNA encoding neuropsin was upregulated after SCI (Fig. 1F). At 1-14 days post-injury, there was a significant increase in neuropsin mRNA expression, peaking at 4 days (days 1 and 14, $P<0.05$; day 7, $P<0.01$; day 4, $P$ $<0.001)$.

\section{Attenuated demyelination in neuropsin ${ }^{-/-}$mice after injury}

Spinal cord sections from WT and neuropsin ${ }^{-/-}$mice at day 14 after SCI were stained with hematoxylin and eosin (Fig. 2). Crush SCI using forceps led to pronounced tissue degeneration in both strains of mice at day 14 after injury (Fig. 2A, B). Although 
tissue degeneration in neuropsin ${ }^{-/-}$mice consisted of a relatively restricted lesion as compared with WT, analysis of lesion areas did not reach significant difference between WT and neuropsin ${ }^{-/-}$mice $(P=0.132$; Fig. 2C).

The results of immunofluorescence labeling for MBP and electron microscopy demonstrated that demyelination was attenuated in neuropsin ${ }^{-/-}$mice (Fig. 3). Extensive defects in MBP immunoreactivity in the spinal cord white matter of WT mice were observed after SCI, whereas in neuropsin ${ }^{-/-}$mice, relatively limited demyelination was observed (Fig. 3A). The image analysis of MBP immunoreactivity indicated that there was a significant difference in the mean IR intensity between WT and neuropsin ${ }^{-/-}$ mice at day 14 after SCI $(P<0.05$; Fig. 3B). Ultrastructual analysis indicated that severe deformed axons and myelin sheaths were observed in WT mice after SCI. Particularly, myelin sheaths of large axons were mostly damaged. In contrast, relatively well-preserved myelin sheaths and axons were observed in neuropsin ${ }^{-/-}$mice $^{-}$ (Fig. 3C). These results indicate that neuropsin is involved in the onset and progression of demyelination.

\section{Attenuated oligodendrocyte death in neuropsin ${ }^{-/}$mice after injury}

The data on TUNEL and activated caspase-3 expression revealed that oligodendrocyte death was attenuated in neuropsin ${ }^{-/-}$mice. Spinal cord sections from WT and neuropsin $^{-/-}$mice at different time points after SCI were processed for TUNEL 
combined with APC immunofluorescence (Fig. 4). SCI resulted in the appearance of a significant number of double-labeled cells positive for TUNEL and APC. These double-labeled cells were distributed mainly in the dorsal, lateral and ventral funiculi of the white matter. A relatively small number of positive cells were also found in the gray matter. These double-labeled cells were counted within the white matter in WT and neuropsin ${ }^{-/-}$mice after SCI. Although both strains of mice showed a significant number of double-labeled cells after SCI, the number was significantly smaller in neuropsin $^{-/-}$mice than WT mice at day $4(P<0.05$; Fig. 4A, B). At day 14 , the number of double-labeled cells was decreased in both strains of mice (Fig. 4B).

Double immunofluorescence labeling for activated caspase-3 and APC was performed on spinal cord sections from WT and neuropsin ${ }^{-/-}$mice at different time points after SCI (Fig. 5). At day 4 after SCI, we found that a significant number of APC-immunoreactive oligodendrocytes showed the expression of activated caspase-3 in WT mice (80.2 \pm 8.9 cells per section; Fig. 5A). These double-labeled cells were distributed in the dorsal, lateral and ventral funiculi of the white matter. A relatively small number of cells positive for activated caspase-3 and APC were also found in neuropsin $^{-/-}$mice (33.6 \pm 3.5 cells per section; Fig. 5A). Western blot analysis showed that the expression of activated caspase-3 was significantly increased at day 4 after SCI in WT mice as compared with neuropsin ${ }^{-/-}$mice $(P<0.05$; Fig. 5B, C).

To evaluate the oligodendrocyte loss caused by injury, spinal cord sections from 
WT and neuropsin ${ }^{-/-}$mice at days 0 and 14 were processed for in situ hybridization for PLP mRNA. As shown in Figure 6, oligodendrocyte loss was attenuated in neuropsin $^{-/-}$mice at day 14 after injury. A large number of PLP mRNA-positive oligodendrocytes were seen in the white matter of the spinal cord from WT and neuropsin $^{-/-}$mice without SCI (Fig. 6A, B). At day 14 after injury, the reduction in the number of PLP mRNA-positive cells was prominent in WT mice (Fig. 6C, E). In contrast, neuropsin ${ }^{-/-}$mice did not show a reduction in the number of cells and there was a significant difference in the number of positive cells between WT and neuropsin ${ }^{-/}$ mice at day 14 after SCI $(P<0.05$; Fig. 6D, E). These results indicate that mature oligodendrocytes suffer from cell death after SCI, possibly through the effect of neuropsin.

\section{Attenuated axonal damage and degeneration in neuropsin ${ }^{-/-}$mice after injury}

Axonal degeneration caused by SCI was assessed by anterograde tract tracing with BDA injected into the sensorimotor cortex at the day of SCI (Fig. 7). This technique allowed us to distinguish viable CST fibers after SCI and axonal degeneration results in decrease in the number of labeled fibers. SCI resulted in prominent axonal degeneration of CST fibers as indicated by a decrease in the density of BDA-labeled fibers caudal to the lesion site at day 14 after injury (Fig. 7A-I). In WT mice, axonal degeneration was observed not only caudal but also rostral to the lesion site (Fig. 7D-F). 
The number of BDA-labeled fibers $1.0 \mathrm{~mm}$ rostral and caudal to the lesion was significantly decreased after SCI in WT mice (Fig. 7J). Neuropsin ${ }^{-/-}$mice also showed degeneration of CST fibers caudal but not rostral to the lesion site (Fig. 7G-I). The number of labeled fibers caudal to the lesion in neuropsin ${ }^{-/-}$mice was significantly larger than that in WT mice although a significant reduction after SCI was observed (Fig. 7J).

\section{Improved recovery of hindlimb function in neuropsin ${ }^{-/-}$mice}

To examine the effect of neuropsin on behavioral phenotypes after SCI, two behavioral tasks, open-field locomotor BBB score and rotorod, were imposed on WT and neuropsin $^{-/-}$mice. As shown in Figure 8, both WT and neuropsin ${ }^{-/-}$mice exhibited initial impairments of motor function. Open-field locomotor performance showed slight voluntary hindlimb movement at day 1 after SCI without a significant difference

between WT and neuropsin ${ }^{-/-}$mice $(P=0.336)$. Neuropsin ${ }^{-/-}$mice showed a significantly more improved recovery from hindlimb impairments than WT mice. Although both strains showed a gradual recovery over a 42-day period, the scores in neuropsin $^{-/-}$mice were significantly higher than those in WT mice $(P<0.05$; Fig. 8A). Similarly, performance on the rotorod was dramatically impaired at day 1 after SCI followed by a gradual recovery over 42 days. At days 10-42, neuropsin ${ }^{-/-}$mice showed a significantly better rotorod performance than WT mice (day $10, P<0.05$; days 14-35, 
$P<0.01$; day 42, $P<0.001$; Fig. 8B). These results indicate that inhibition of neuropsin activity may improve functional outcome after SCI. 


\section{Discussion}

The series of experiments in this study show the potential involvement of neuropsin in the secondary damage after SCI. Consistent with previous studies, the expression of neuropsin mRNA in WT mice was increased in the white matter of the spinal cord after injury (Tomizawa et al., 1999; Terayama et al., 2004). Extending on previous results, our findings demonstrate that neuropsin may promote oligodendrocyte death, demyelination and axonal degeneration after SCI. Using mice lacking neuropsin, we examined the histopathology and recovery from initial impairments of hindlimb function after SCI. We found that neurop $\sin ^{-/-}$mice exhibit (1) attenuated demyelination and oligodendrocyte death; (2) attenuated axonal damage and degeneration; and (3) improved recovery of hindlimb function.

Oligodendrocyte death is a prominent feature of the secondary degeneration after SCI (Lu et al., 2000; Blight, 2002; Dong et al., 2003; Park et al., 2004). Several lines of evidence have suggested that glutamate excitotoxicity plays a key role not only in neuronal cell death but also in delayed post traumatic spinal cord white matter degeneration (Faden and Simon, 1988; Wrathall et al., 1994; Agrawal and Fehlings, 1997; Wrathall et al., 1997). Oligodendrocytes are highly vulnerable to excitotoxic signals mediated by glutamate receptors of the AMPA and kainate classes compared to astrocytes (Oka et al., 1993; Yoshioka et al., 1996; Agrawal and Fehlings, 1997; Matute 
et al., 1997; McDonald et al., 1998). Our previous experiments showed that excitotoxic injury caused by injection of kainate into the CNS induced expression of neuropsin mRNA in oligodendrocytes (Tomizawa et al., 1999). Furthermore, it has been shown that the proteolytic activation of neuropsin is induced in a glutamate receptor-dependent manner (Matsumoto-Miyai et al., 2003). Neuropsin is therefore induced in situations of excitation in oligodendrocytes and a subset of neurons. The results of the present study demonstrated that SCI induced neuropsin mRNA expression in the white matter and neuropsin ${ }^{-/-}$mice showed attenuated oligodendrocyte death. In our recent study using an experimental autoimmune encephalomyelitis paradigm, we also showed attenuated oligodendrocyte death in neuropsin ${ }^{-/-}$mice (Terayama et al., 2005a). It has been reported that tissue plasminogen activator (tPA), a serine protease, mediates excitotoxic neuronal death in the hippocampus through degradation of extracellular laminin (Chen and Strickland, 1997; Tsirka et al., 1997). It is possible that neuropsin degrades laminin or other extracellular matrix proteins, which are essential for oligodendrocyte survival. Although further study will be needed to determine substrates for neuropsin and to establish the relevance of neuropsin to AMPA or kainate receptors, both previous and present results suggest that neuropsin is involved, at least in part, in excitotoxic oligodendrocyte death mediated by glutamate receptors.

Although neuropsin has been shown to be involved in oligodendrocyte death, which may secondarily cause demyelination, proteolytic activity of neuropsin can also 
be considered to mediate demyelination in the pathology of SCI. It has been suggested that oligodendrocytes and myelin have endogenous protease activity with the potential to degrade myelin proteins (Sato et al., 1982; Berlet et al., 1984; Chantry et al., 1989; Scarisbrick et al., 2002; Terayama et al., 2005b). The in vitro biochemical assay showed that neuropsin is capable of degrading MBP (He et al., 2001). This activity would indicate that neuropsin functions in demyelination through the proteolysis of myelin proteins. The results of immunofluorescence labeling for MBP and electron microscopy in WT and neuropsin ${ }^{-/-}$mice also indicate that neuropsin is involved in demyelination.

One of the most striking results in this study was that neuropsin ${ }^{-/-}$mice showed a significantly improved recovery from initial impairments of hindlimb function. SCI extends temporally and spatially from early neuronal death at the focal lesion site to degeneration of the related white matter fiber tracts weeks after injury. Degradation of neurofilaments and loss of axonal integrity has been reported as early as 15 min after experimental SCI (Banik et al., 1982; Schumacher et al., 1999; Schumacher et al., 2000). The concurrent loss of oligodendrocytes in degenerating axon tracts suggests an intimate relationship between oligodendrocyte survival and axonal integrity (Barres et al., 1993; Crowe et al., 1997; Warden et al., 2001). Since oligodendrocytes myelinate several axons simultaneously, the loss of a single cell can influence neighboring axons. The results of electron microscopy and anterograde tract tracing with BDA also indicate 
attenuation of axonal degeneration in neuropsin ${ }^{-/-}$mice after SCI. These results suggest that oligodendrocyte loss related with neuropsin activity may be involved in axonal damage and degeneration although the causal relationship between oligodendrocyte death and axonal degeneration remains to be clarified. The possibility that oligodendrocyte loss and demyelination may lead to axonal degeneration was supported by the finding that myelination provides an extrinsic trophic signal to axons that increases axonal caliber and the loss of this effect can result in axonal degeneration (Windebank et al., 1985; Trapp et al., 1989; Fruttiger et al., 1995; Sanchez et al., 1996).

Although the present work indicates a detrimental role of increased neuropsin activity after SCI, other serine proteases such as tPA or matrix metalloproteinases (MMPs) play important roles in the pathology after CNS injury (Noble Lj Fau Donovan et al., 2002; Abe Y Fau - Nakamura et al., 2003; Wells Je Fau - Rice et al., 2003). These proteases are expressed by neurons, astrocytes, microglia or inflammatory cells, whereas neuropsin is expressed exclusively by oligodendrocytes (Terayama et al., 2004). Thus, it is likely that neuropsin functions to modify the extracellular environment with these proteases after injury.

It has been reported that the expression of neuropsin is induced in several pathological conditions in the CNS including excitotoxic, traumatic or immunological injury, seizure and Alzheimer's disease (Okabe et al., 1996; Tomizawa et al., 1999; He et al., 2001; Shimizu-Okabe et al., 2001; Terayama et al., 2004; Terayama et al., 2005a). 
Although neuropsin has normal biological functions such as neuronal plasticity and neural development (Yoshida and Shiosaka, 1999), the overexpression of neuropsin could be associated with neuronal and glial dysfunction or cell death, and have detrimental effects on the CNS. The increased expression of neuropsin mRNA in Alzheimer hippocampus could be partly attributed to the induction occurring in oligodendrocytes.

In summary, we showed here the involvement of neuropsin in the secondary mechanisms after SCI. Neuropsin may contribute to the onset and progression of demyelination, oligodendrocyte death, and axonal degeneration. Although further study will be needed to elucidate the role of neuropsin using a specific inhibitor for neuropsin in WT mice after SCI, our results suggest that attenuation of neuropsin activity could prove beneficial in combination with the existing therapeutic management of SCI.

\section{Acknowledgements}

This work was partly supported by grants from the Ministry of Education, Science, Culture and Sports of Japan, the Noastec Grant, the Akiyama Foundation and the Inamori Foundation. We thank Dr. Sadao Shiosaka for providing neuropsin ${ }^{-/-}$mice and his comments on this manuscript. 


\section{REFERENCES}

Abe Y Fau - Nakamura H, Nakamura H Fau - Yoshino O, Yoshino O Fau - Oya T, Oya T Fau - Kimura T, Kimura T (2003) Decreased neural damage after spinal cord injury in tPA-deficient mice. J Neurotrauma 20:43-57.

Agrawal SK, Fehlings MG (1997) Role of NMDA and non-NMDA ionotropic glutamate receptors in traumatic spinal cord axonal injury. J Neurosci 17:1055-1063.

Banik NL, Hogan EL, Powers JM, Whetstine LJ (1982) Degradation of cytoskeletal proteins in experimental spinal cord injury. Neurochem Res 7:1465-1475.

Barres BA, Jacobson MD, Schmid R, Sendtner M, Raff MC (1993) Does oligodendrocyte survival depend on axons? Curr Biol 3:489-497.

Basso DM, Beattie MS, Bresnahan JC (1995) A sensitive and reliable locomotor rating scale for open field testing in rats. J Neurotrauma 12:1-21.

Berlet HH, Ilzenhofer H, Schulz G (1984) Cleavage of myelin basic protein by neutral protease activity of human white matter and myelin. J Neurochem 43:627-633.

Blight AR (2002) Miracles and molecules--progress in spinal cord repair. Nat Neurosci 5:1051-1054.

Borgono CA, Diamandis EP (2004) The emerging roles of human tissue kallikreins in 
cancer. Nat Rev Cancer 4:876-890.

Borgono CA, Michael IP, Diamandis EP (2004) Human tissue kallikreins: physiologic roles and applications in cancer. Mol Cancer Res 2:257-280.

Chantry A, Gregson NA, Glynn P (1989) A novel metalloproteinase associated with brain myelin membranes. Isolation and characterization. J Biol Chem 264:21603-21607.

Chen ZL, Strickland S (1997) Neuronal death in the hippocampus is promoted by plasmin-catalyzed degradation of laminin. Cell 91:917-925.

Chen ZL, Momota Y, Kato K, Taniguchi M, Inoue N, Shiosaka S, Yoshida S (1998) Expression of neuropsin mRNA in the mouse embryo and the pregnant uterus. J Histochem Cytochem 46:313-320.

Chen ZL, Yoshida S, Kato K, Momota Y, Suzuki J, Tanaka T, Ito J, Nishino H, Aimoto S, Kiyama H, et al. (1995) Expression and activity-dependent changes of a novel limbic-serine protease gene in the hippocampus. J Neurosci $15: 5088-5097$.

Crowe MJ, Bresnahan JC, Shuman SL, Masters JN, Beattie MS (1997) Apoptosis and delayed degeneration after spinal cord injury in rats and monkeys. Nat Med 3:73-76.

Diamandis EP, Yousef GM, Olsson AY (2004) An update on human and mouse glandular kallikreins. Clin Biochem 37:258-260. 
Dong H, Fazzaro A, Xiang C, Korsmeyer SJ, Jacquin MF, McDonald JW (2003) Enhanced oligodendrocyte survival after spinal cord injury in Bax-deficient mice and mice with delayed Wallerian degeneration. J Neurosci 23:8682-8691.

Faden AI, Simon RP (1988) A potential role for excitotoxins in the pathophysiology of spinal cord injury. Ann Neurol 23:623-626.

Faulkner JR, Herrmann JE, Woo MJ, Tansey KE, Doan NB, Sofroniew MV (2004) Reactive astrocytes protect tissue and preserve function after spinal cord injury. J Neurosci 24:2143-2155.

Fruttiger M, Montag D, Schachner M, Martini R (1995) Crucial role for the myelin-associated glycoprotein in the maintenance of axon-myelin integrity. Eur J Neurosci 7:511-515.

He XP, Shiosaka S, Yoshida S (2001) Expression of neuropsin in oligodendrocytes after injury to the CNS. Neurosci Res 39:455-462.

Hirata A, Yoshida S, Inoue N, Matsumoto-Miyai K, Ninomiya A, Taniguchi M, Matsuyama T, Kato K, Iizasa H, Kataoka Y, Yoshida N, Shiosaka S (2001) Abnormalities of synapses and neurons in the hippocampus of neuropsin-deficient mice. Mol Cell Neurosci 17:600-610.

Inman D, Guth L, Steward O (2002) Genetic influences on secondary degeneration and wound healing following spinal cord injury in various strains of mice. $\mathrm{J}$ 
Comp Neurol 451:225-235.

Kirihara T, Matsumoto-Miyai K, Nakamura Y, Sadayama T, Yoshida S, Shiosaka S (2003) Prolonged recovery of ultraviolet B-irradiated skin in neuropsin (KLK8)-deficient mice. Br J Dermatol 149:700-706.

Krystosek A, Seeds NW (1981) Plasminogen activator release at the neuronal growth cone. Science 213:1532-1534.

Lu J, Ashwell KW, Waite P (2000) Advances in secondary spinal cord injury: role of apoptosis. Spine 25:1859-1866.

Matsumoto-Miyai K, Ninomiya A, Yamasaki H, Tamura H, Nakamura Y, Shiosaka S (2003) NMDA-dependent proteolysis of presynaptic adhesion molecule L1 in the hippocampus by neuropsin. J Neurosci 23:7727-7736.

Matute C, Sanchez-Gomez MV, Martinez-Millan L, Miledi R (1997) Glutamate receptor-mediated toxicity in optic nerve oligodendrocytes. Proc Natl Acad Sci U S A 94:8830-8835.

McDonald JW, Althomsons SP, Hyrc KL, Choi DW, Goldberg MP (1998) Oligodendrocytes from forebrain are highly vulnerable to AMPA/kainate receptor-mediated excitotoxicity. Nat Med 4:291-297.

Mocchetti I, Wrathall JR (1995) Neurotrophic factors in central nervous system trauma. J Neurotrauma 12:853-870.

Monard D (1988) Cell-derived proteases and protease inhibitors as regulators of 
neurite outgrowth. Trends Neurosci 11:541-544.

Noble Lj Fau - Donovan F, Donovan F Fau - Igarashi T, Igarashi T Fau - Goussev S, Goussev S Fau - Werb Z, Werb Z (2002) Matrix metalloproteinases limit functional recovery after spinal cord. J Neurosci 22:7526-7535.

Oka A, Belliveau MJ, Rosenberg PA, Volpe JJ (1993) Vulnerability of oligodendroglia to glutamate: pharmacology, mechanisms, and prevention. J Neurosci 13:1441-1453.

Okabe A, Momota Y, Yoshida S, Hirata A, Ito J, Nishino H, Shiosaka S (1996) Kindling induces neuropsin mRNA in the mouse brain. Brain Res 728:116-120.

Park E, Velumian AA, Fehlings MG (2004) The role of excitotoxicity in secondary mechanisms of spinal cord injury: a review with an emphasis on the implications for white matter degeneration. J Neurotrauma 21:754-774.

Sanchez I, Hassinger L, Paskevich PA, Shine HD, Nixon RA (1996) Oligodendroglia regulate the regional expansion of axon caliber and local accumulation of neurofilaments during development independently of myelin formation. J Neurosci 16:5095-5105.

Sanes JR (1983) Roles of extracellular matrix in neural development. Annu Rev Physiol 45:581-600.

Sanes JR (1989) Extracellular matrix molecules that influence neural development. 
Annu Rev Neurosci 12:491-516.

Sato S, Quarles RH, Brady RO (1982) Susceptibility of the myelin-associated glycoprotein and basic protein to a neutral protease in highly purified myelin from human and rat brain. J Neurochem 39:97-105.

Scarisbrick IA, Blaber SI, Lucchinetti CF, Genain CP, Blaber M, Rodriguez M (2002) Activity of a newly identified serine protease in CNS demyelination. Brain 125:1283-1296.

Schumacher PA, Eubanks JH, Fehlings MG (1999) Increased calpain I-mediated proteolysis, and preferential loss of dephosphorylated NF200, following traumatic spinal cord injury. Neuroscience 91:733-744.

Schumacher PA, Siman RG, Fehlings MG (2000) Pretreatment with calpain inhibitor CEP-4143 inhibits calpain I activation and cytoskeletal degradation, improves neurological function, and enhances axonal survival after traumatic spinal cord injury. J Neurochem 74:1646-1655.

Seeds NW, Haffke S, Christensen K, Schoonmaker J (1990) Cerebellar granule cell migration involves proteolysis. Adv Exp Med Biol 265:169-178.

Shimizu C, Yoshida S, Shibata M, Kato K, Momota Y, Matsumoto K, Shiosaka T, Midorikawa R, Kamachi T, Kawabe A, Shiosaka S (1998) Characterization of recombinant and brain neuropsin, a plasticity-related serine protease. J Biol Chem 273:11189-11196. 
Shimizu-Okabe C, Yousef GM, Diamandis EP, Yoshida S, Shiosaka S, Fahnestock M (2001) Expression of the kallikrein gene family in normal and Alzheimer's disease brain. Neuroreport 12:2747-2751.

Shiosaka S, Yoshida S (2000) Synaptic microenvironments--structural plasticity, adhesion molecules, proteases and their inhibitors. Neurosci Res 37:85-89.

Terayama R, Bando Y, Takahashi T, Yoshida S (2004) Differential expression of neuropsin and protease $\mathrm{M}$ /neurosin in oligodendrocytes after injury to the spinal cord. Glia 48:91-101.

Terayama R, Bando Y, Yamada M, Yoshida S (2005a) Involvement of neuropsin in the pathogenesis of experimental autoimmune encephalomyelitis. Glia 52:108-118.

Terayama R, Bando Y, Jiang Y-P, Mitrovic B, Yoshida S (2005b) Differential expression of protease $\mathrm{M} /$ neurosin in oligodendrocytes and their progenitors in an animal model of multiple sclerosis. Neurosci Lett 382:82-87.

Tomizawa K, He X, Yamanaka H, Shiosaka S, Yoshida S (1999) Injury induces neuropsin mRNA in the central nervous system. Brain Res 824:308-311.

Trapp BD, Andrews SB, Cootauco C, Quarles R (1989) The myelin-associated glycoprotein is enriched in multivesicular bodies and periaxonal membranes of actively myelinating oligodendrocytes. J Cell Biol 109:2417-2426.

Tsirka SE, Bugge TH, Degen JL, Strickland S (1997) Neuronal death in the central 
nervous system demonstrates a non-fibrin substrate for plasmin. Proc Natl Acad Sci U S A 94:9779-9781.

Warden P, Bamber NI, Li H, Esposito A, Ahmad KA, Hsu CY, Xu XM (2001) Delayed glial cell death following wallerian degeneration in white matter tracts after spinal cord dorsal column cordotomy in adult rats. Exp Neurol 168:213-224.

Wells Je Fau - Rice TK, Rice Tk Fau - Nuttall RK, Nuttall Rk Fau - Edwards DR, Edwards Dr Fau - Zekki H, Zekki H Fau - Rivest S, Rivest S Fau - Yong VW, Yong VW (2003) An adverse role for matrix metalloproteinase 12 after spinal cord injury. J Neurosci 23:10107-10115.

Windebank AJ, Wood P, Bunge RP, Dyck PJ (1985) Myelination determines the caliber of dorsal root ganglion neurons in culture. J Neurosci 5:1563-1569.

Wrathall JR, Choiniere D, Teng YD (1994) Dose-dependent reduction of tissue loss and functional impairment after spinal cord trauma with the AMPA/kainate antagonist NBQX. J Neurosci 14:6598-6607.

Wrathall JR, Teng YD, Marriott R (1997) Delayed antagonism of AMPA/kainate receptors reduces long-term functional deficits resulting from spinal cord trauma. Exp Neurol 145:565-573.

Yoshida S, Shiosaka S (1999) Plasticity-related serine proteases in the brain (review). Int J Mol Med 3:405-409. 
Yoshida S, Taniguchi M, Hirata A, Shiosaka S (1998) Sequence analysis and expression of human neuropsin cDNA and gene. Gene 213:9-16.

Yoshida S, Lin LP, Chen ZL, Momota Y, Kato K, Tanaka T, Wanaka A, Shiosaka S (1994) Basal magnocellular and pontine cholinergic neurons coexpress FGF receptor mRNA. Neurosci Res 20:35-42.

Yoshioka A, Bacskai B, Pleasure D (1996) Pathophysiology of oligodendroglial excitotoxicity. J Neurosci Res 46:427-437.

Yousef GM, Kishi T, Diamandis EP (2003) Role of kallikrein enzymes in the central nervous system. Clin Chim Acta 329:1-8.

Zhang Z, Fujiki M, Guth L, Steward O (1996) Genetic influences on cellular reactions to spinal cord injury: a wound-healing response present in normal mice is impaired in mice carrying a mutation (WldS) that causes delayed Wallerian degeneration. J Comp Neurol 371:485-495. 
Table 1. Numbers of animals used for each experimental procedure

\begin{tabular}{|c|c|c|c|c|c|}
\hline \multirow[b]{2}{*}{ Experimental procedure } & \multirow[b]{2}{*}{ control } & \multicolumn{4}{|c|}{ Spinal cord injury } \\
\hline & & day 1 & day 4 & day 7 & day 14 \\
\hline
\end{tabular}

Transverse sections $^{a}$
WT / neuropsin ${ }^{-/-}$
$5 / 5$
$5 / 5$
$5 / 5$

Lesion size analysis

WT / neuropsin ${ }^{-/-}$

Electron microscopy

WT / neuropsin ${ }^{-/-}$

Anterograde tract tracing with BDA
WT / neuropsin ${ }^{-/-}$
$5 / 5$

$5 / 5$

Real-time quantitative PCR

WT

3

3

3

3

3

Western blot analysis

WT / neuropsin ${ }^{-/-}$

$3 / 3$

$3 / 3$

Behavioral analysis
WT / neuropsin ${ }^{-/-}$
$8 / 8$ (day 0-42)

${ }^{a}$ These sections were used for in situ hybridization, immunofluorescence labeling and TUNEL. 


\section{Figure legends}

Figure 1

(A) Schematic illustration of crush SCI model. (B) A horizontal section stained with hematoxylin and eosin at day 14 after SCI showing damaged spinal cord tissue. The injury site is indicated with arrowheads. (C-E) Expression of neuropsin mRNA in the spinal cord after crush injury. In situ hybridization was performed with a probe for neuropsin on cross sections within 400-600 $\mu \mathrm{m}$ rostral to the epicenter. (C) In the untreated control mouse spinal cord, no neuropsin mRNA was found in the white matter, while a small number of cells in the gray matter expressed neuropsin mRNA. (D) Neuropsin mRNA expression at day 4 after SCI is shown. Neuropsin mRNA expression was induced in the white matter immediately adjacent to the lesion.

Higher magnification of the boxed area in D. (F) SCI-induced changes in neuropsin mRNA expression in the spinal cord. Levels of specific mRNA were measured by quantitative real-time PCR and normalized with the level of GAPDH mRNA expression in each individual sample. Each bar represents the mean \pm SEM of 3 individual experiments. Statistical comparisons were made among all groups. Asterisks indicate significant differences from naive control (ANOVA with post hoc Fisher's PLSD test), ${ }^{*} P<0.05 ;{ }^{* *} P<0.01 ;{ }^{* * *} P<0.001$. g, gray matter; $\mathrm{w}$, white matter. Scale bars $=500 \mu \mathrm{m}$ in $\mathrm{B}$ and $\mathrm{D}$, and $100 \mu \mathrm{m}$ in $\mathrm{E}$. 
Figure 2

Tissue degeneration of spinal cord in WT and neuropsin ${ }^{-/-}$mice after SCI. (A, B) Horizontal sections of lower thoracic and upper lumber spinal cord (rostral is the left) encompassing the lesion area and containing the central canal from WT (A) and neuropsin $^{-/-}$(B) mice at day 14 after SCI. Lesion areas were outlined using Lumina Vision software and the lesion size was calculated for statistical analysis. (C) Each bar represents the mean lesion size \pm SEM determined from 5 individual experiments. Statistical comparisons were made between WT and neuropsin ${ }^{-/-}$mice (Student's $t$-test). Scale bar $=500 \mu \mathrm{m}$.

Figure 3

Attenuated demyelination in neuropsin ${ }^{-/-}$mice after SCI. (A) Immunofluorescence labeling for MBP on cross sections in the ventral funiculus of the spinal cord within 400-600 $\mu \mathrm{m}$ rostral to the epicenter from WT and neuropsin ${ }^{-/-}$mice at days 0,4 and 14 after SCI. Note that prominent defects in MBP immunoreactivity were obvious in WT mice at day 14 after SCI, whereas less extensive demyelination was found in neuropsin ${ }^{--}$mice. (B) The IR intensities were measured from the whole white matter of the spinal cord sections within 400-600 $\mu \mathrm{m}$ rostral and caudal to the epicenter at days 0, 4 and 14 after SCI. Each bar represents the mean IR intensity \pm SEM determined 
from 5 individual experiments. Statistical comparisons were made between WT and neuropsin $^{-/-}$mice at each time point $(* P<0.05$, Student's $t$-test). (C) Electron micrographs representing the severed spinal cord white matter from WT and neuropsin ${ }^{-/-}$ mice at day 14 after SCI. Note that severe deformed axons (X) and myelin sheaths (arrows) were observed in WT mice, whereas relatively well-preserved myelin sheaths and axons (asterisks) were observed in neuropsin ${ }^{-/-}$mice. Scale bars $=200 \mu \mathrm{m}$ and 2 $\mu \mathrm{m}$ in $\mathrm{A}$ and $\mathrm{D}$, respectively.

Figure 4

Attenuated oligodendrocyte death in neuropsin ${ }^{-/-}$mice after SCI. Cross sections in the ventral funiculus of the spinal cord within $400-600 \mu \mathrm{m}$ rostral to the epicenter are shown. (A) Using TUNEL combined with APC immunofluorescence labeling, a significant number of oligodendrocytes showing DNA fragmentation were detected in the ventral funiculus of the spinal cord from WT mice at day 4 (arrows), whereas a significantly smaller number of double-labeled cells were detected in neuropsin ${ }^{-/-}$mice. $^{-}$ (B) The number of double-labeled cells was counted in the white matter of the spinal cord within 400-600 $\mu \mathrm{m}$ rostral and caudal to the epicenter at days 4 and 14 after SCI. Each bar represents the mean number \pm SEM of 5 individual experiments. Statistical comparisons were made between WT and neuropsin ${ }^{-/-}$mice at each time point $(* P<$ 0.05, Student's $t$-test). Scale bar=100 $\mu \mathrm{m}$. 
Figure 5

Attenuated expression of activated caspase-3 in neuropsin ${ }^{--}$mice after SCI. (A) Cross sections in the ventral funiculus of the spinal cord within 400-600 $\mu \mathrm{m}$ rostral to the epicenter are shown. A significant number of APC-immunoreactive oligodendrocytes showing activated caspase-3 expression were detected in the ventral funiculus of the spinal cord from WT mice at day 4 (arrows), whereas these double-labeled cells were rarely found in neuropsin ${ }^{-/-}$mice. (B) Western blot analysis of the spinal cord lysates from WT and neuropsin ${ }^{-/-}$mice after SCI using anti-activated caspase-3 antibody. Even loading was demonstrated using an anti-tubulin antibody. (C) Each bar represents the mean expression level \pm SEM determined from 3 individual experiments. Statistical comparisons were made between WT and neuropsin ${ }^{-/-}$mice at each time point ( ${ }^{*} P<0.05$, Student's $t$-test). Scale bar $=100 \mu \mathrm{m}$.

Figure 6

Attenuated oligodendrocyte loss in neuropsin ${ }^{-/-}$mice after SCI. (A-D) Spinal cord sections within 400-600 $\mu \mathrm{m}$ rostral to the epicenter from WT (A, C) and neuropsin ${ }^{-/-}$(B, D) mice at days 0 (A, B) and 14 (C, D) were processed for in situ hybridization for PLP mRNA. Loss of PLP mRNA-positive cells was obvious in the ventral funiculus of the spinal cord from WT mice at day 14 after SCI (C). In neuropsin ${ }^{-/-}$mice, PLP 
mRNA-positive cells were relatively preserved (D). (E) The number of PLP mRNA-positive cells was counted in a fixed area $(250 \mu \mathrm{m} \times 180 \mu \mathrm{m})$ within 400-600 $\mu \mathrm{m}$ rostral and caudal to the epicenter from WT and neuropsin ${ }^{-/-}$mice at days 0 and 14 after SCI. Each bar represents the mean \pm SEM of 3 individual experiments. Statistical comparisons were made between WT and neuropsin ${ }^{-/-}$mice at each time point (**P<0.01, Student's $t$-test). Scale bar $=100 \mu \mathrm{m}$.

Figure 7

Degeneration of axons was assessed by anterograde tract tracing with BDA. (A-I) Horizontal sections of the spinal cord (rostral is the left) from WT mice of the unlesioned control (A-C), and WT (D-F) and neuropsin ${ }^{-/-}$(G-I) mice at day 14 after SCI are shown. (B, C, E, F, H, I) Higher magnification images of respective boxed areas in A, D and G. In WT mice, a decrease in the density of BDA-labeled CST fibers was seen rostral and caudal to the lesion site after SCI (D-F). Neuropsin ${ }^{-/-}$mice also showed axonal degeneration caudal but not rostral to the lesion (G-I). Arrows in I indicate surviving axons caudal to the lesion. The injury site is indicated with arrowheads. (J) The number of CST fibers $1.0 \mathrm{~mm}$ rostral and caudal to the epicenter at days 0 and 14 after SCI. Each bar represents the mean \pm SEM of 5 individual experiments. Asterisks at each bar indicate significant differences from respective naïve controls $\left({ }^{*} P<0.05 ;{ }^{* *} P<0.01 ;{ }^{* * *} P<0.001\right.$, Student's $t$-test). Statistical 
comparisons were also made between WT and neuropsin ${ }^{-/-}$mice in each condition $\left({ }^{*} P<\right.$ 0.05, Student's $t$-test). Scale bars $=500 \mu \mathrm{m}$ and $100 \mu \mathrm{m}$ in $\mathrm{G}$ and I, respectively.

Figure 8

Improved functional recovery after crush SCI in neuropsin ${ }^{-/-}$mice. (A) Time course of hindlimb locomotor performance in an open field over 42 days after SCI in WT and neuropsin ${ }^{-/-}$mice. WT mice $(n=8)$ exhibited initial impairments of hindlimb performance after SCI that gradually recovered over 42 days. Neuropsin ${ }^{-/-}$mice $(n=$ 8) also showed initial impairments of hindlimb performance followed by a gradual recovery, with the scores at days 10-42 being significantly higher than in WT mice (Student's $t$-test, $* P<0.05)$. (B) Time course of rotorod performance over 42 days after SCI in WT and neuropsin ${ }^{-/-}$mice. Both strains of mice exhibited initial impairments of rotorod performance followed by a gradual recovery, but neuropsin ${ }^{-/-}$ mice showed a significantly improved performance at days 10-42. Asterisks indicate significant differences between WT and neuropsin ${ }^{-/-}$mice (Student's $t$-test, $* P<0.05$; $\left.{ }^{* *} P<0.01 ; * * * P<0.001\right)$. 

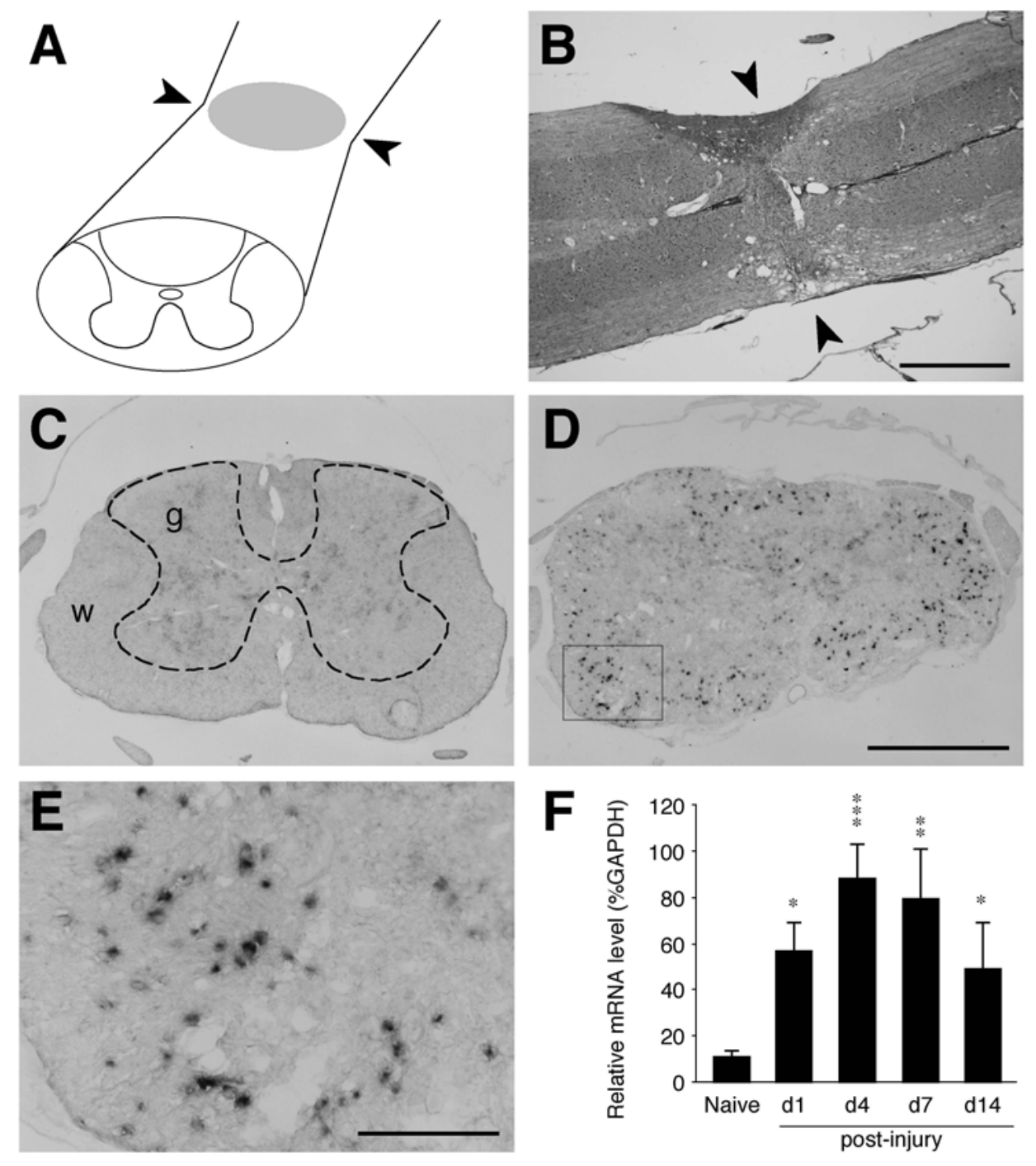

Figure. 1 

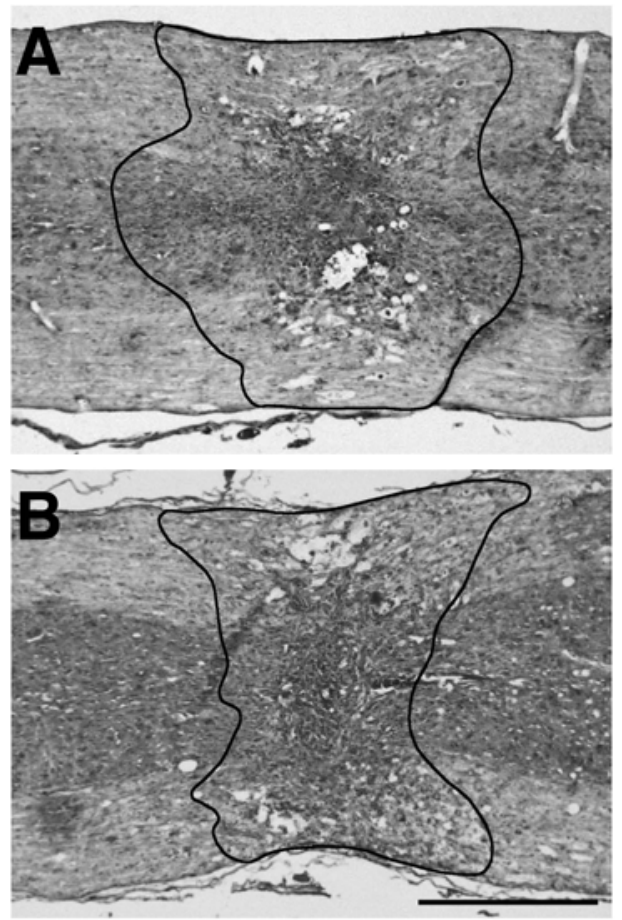

\section{C}

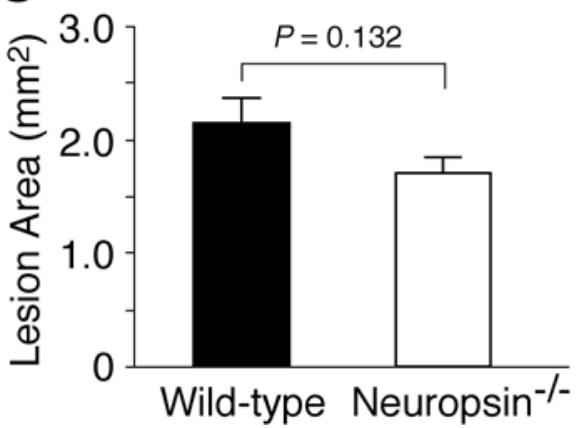

Figure 2 


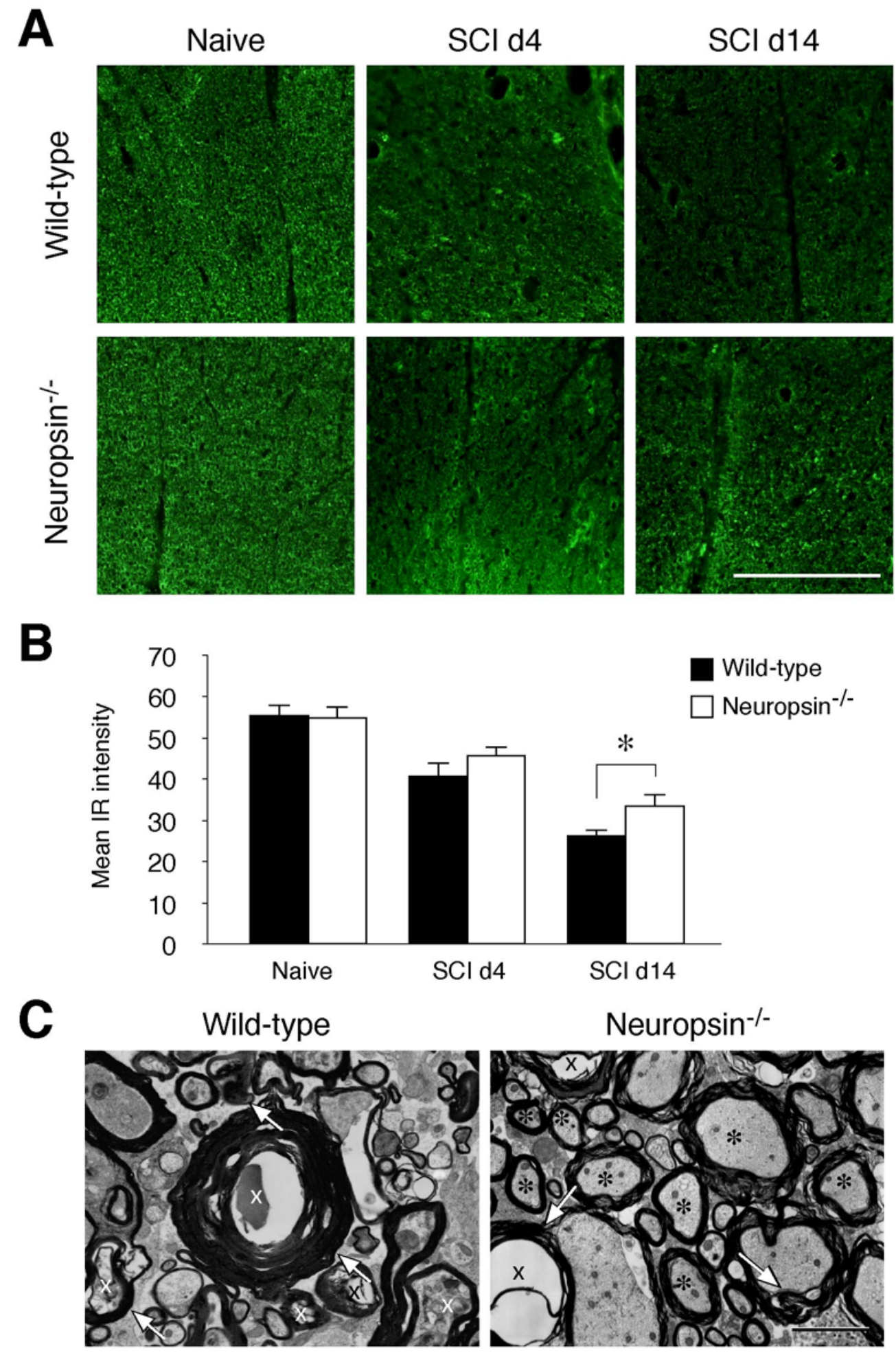

Figure 3 
A TUNEL

APC

merged
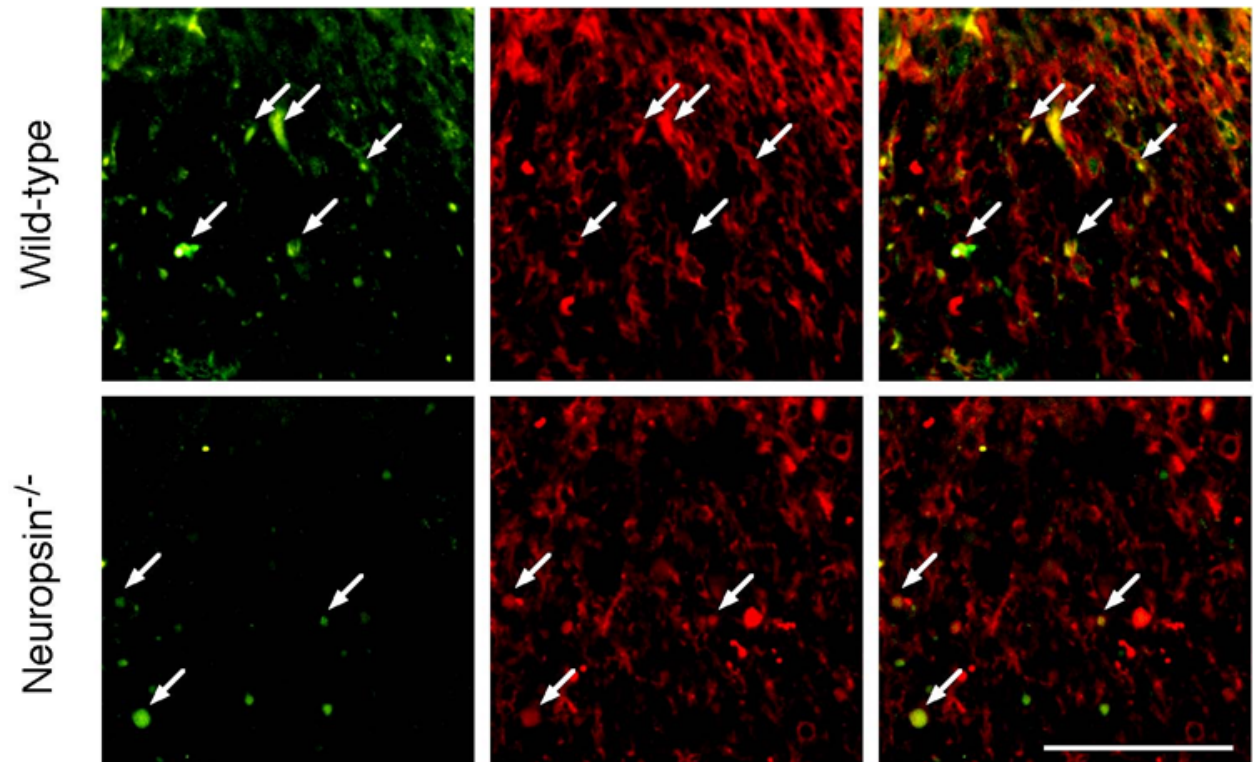

B

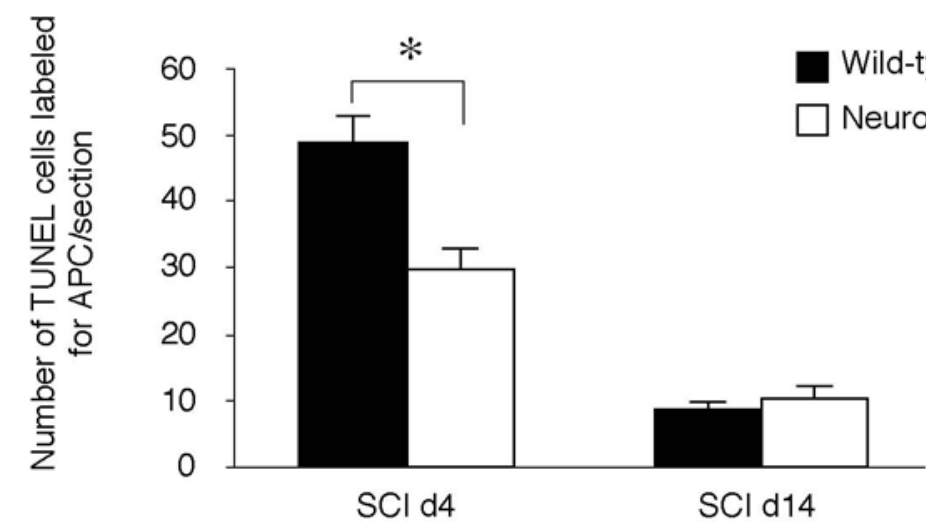

Figure 4 


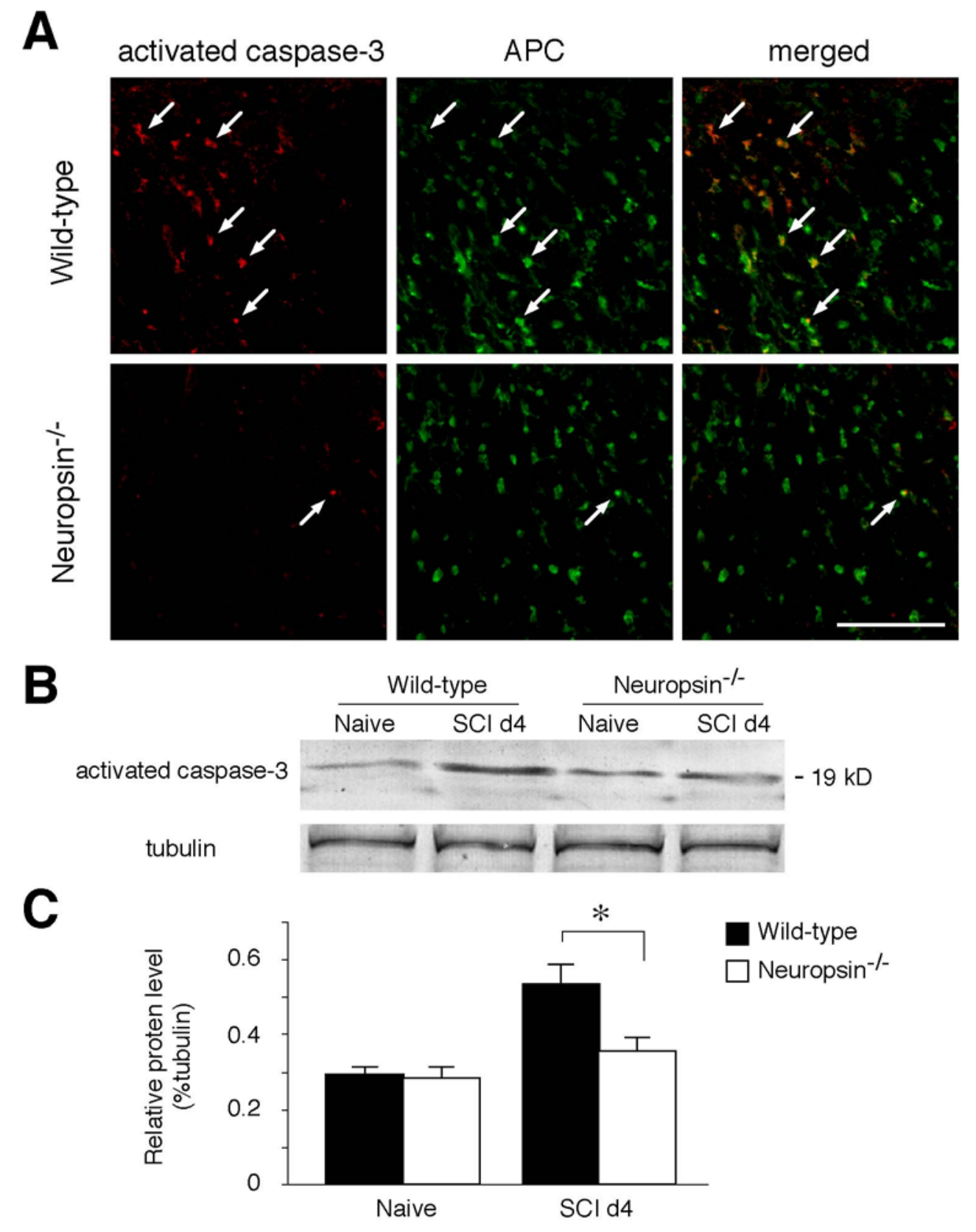

Figure 5 

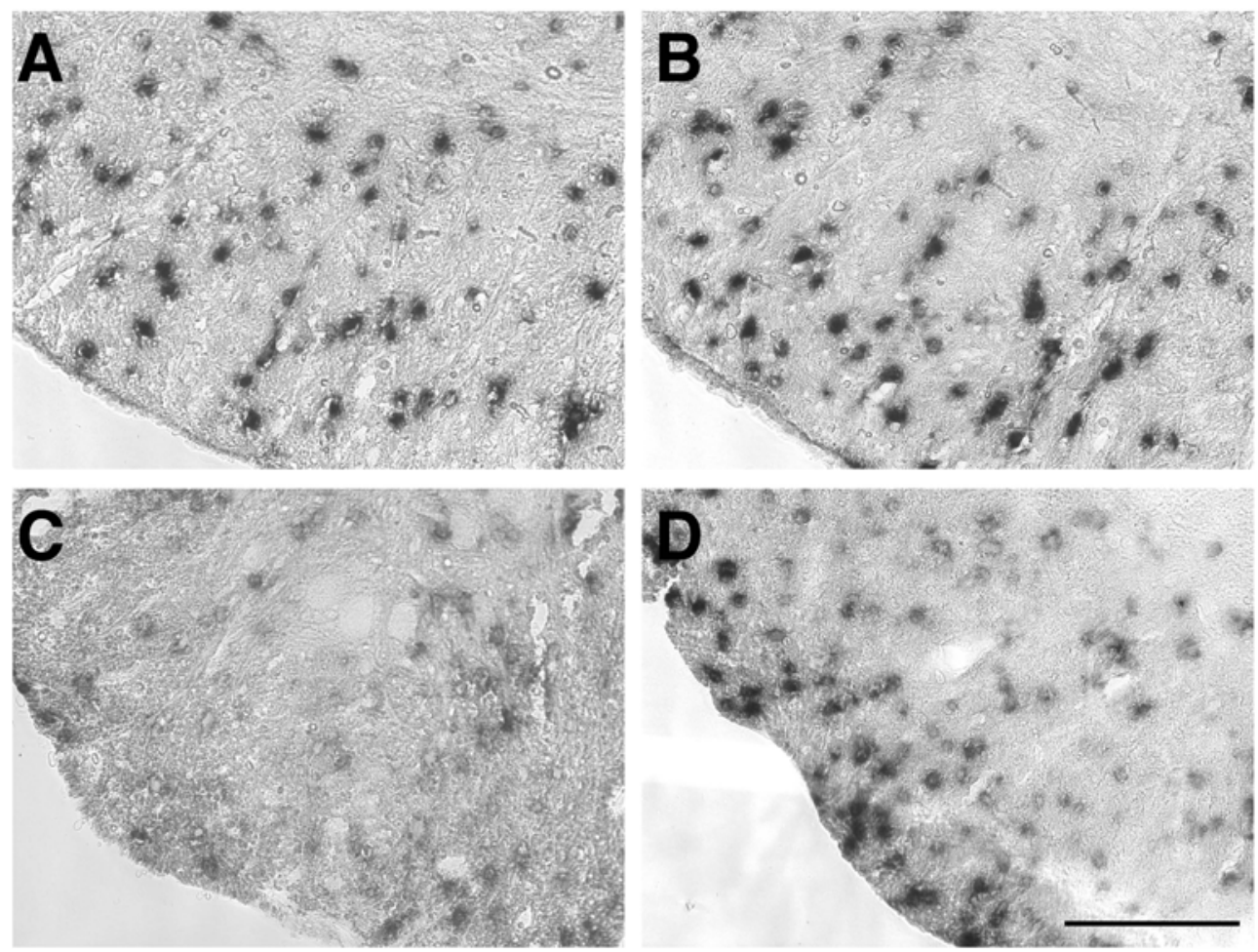

E

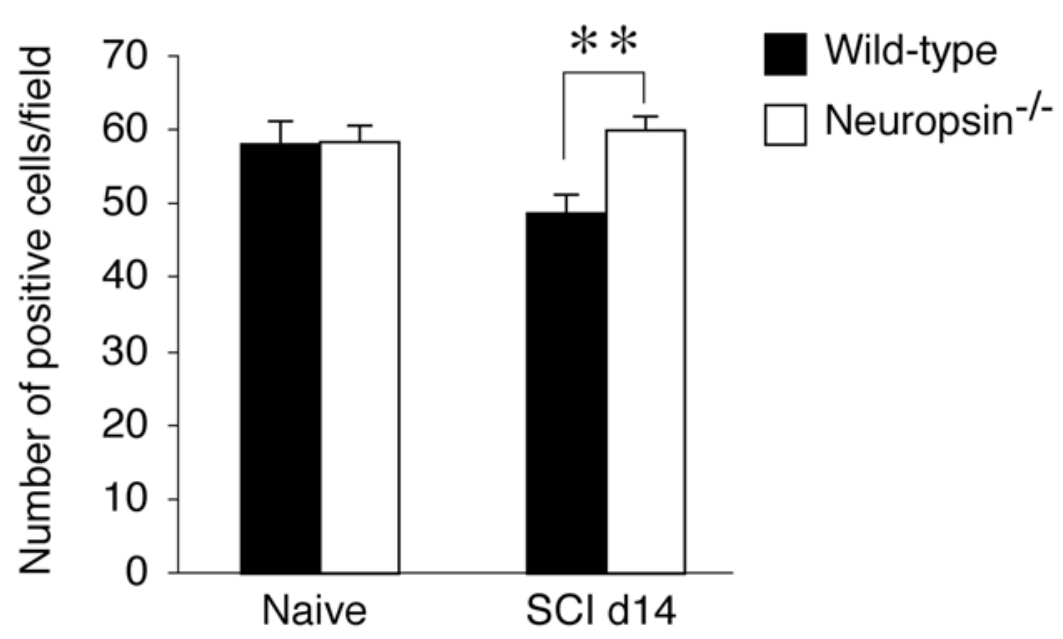

Figure 6 

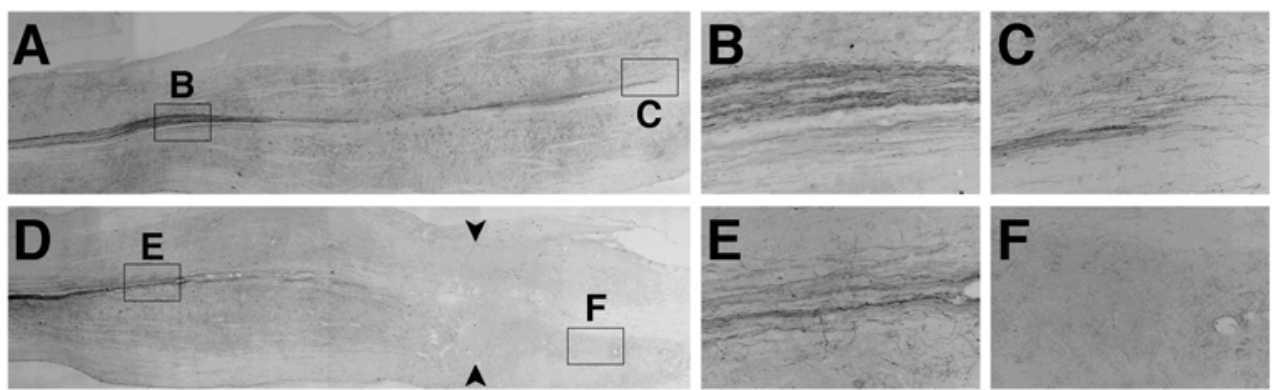

F
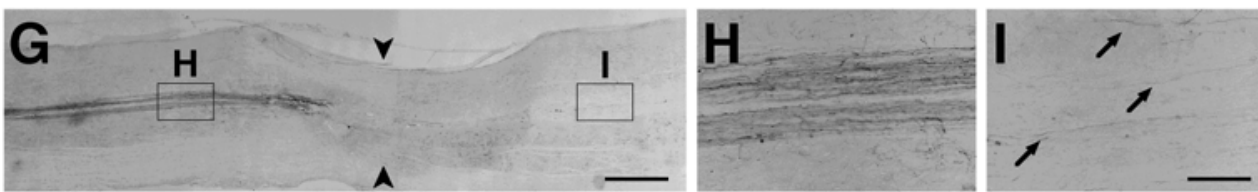

J

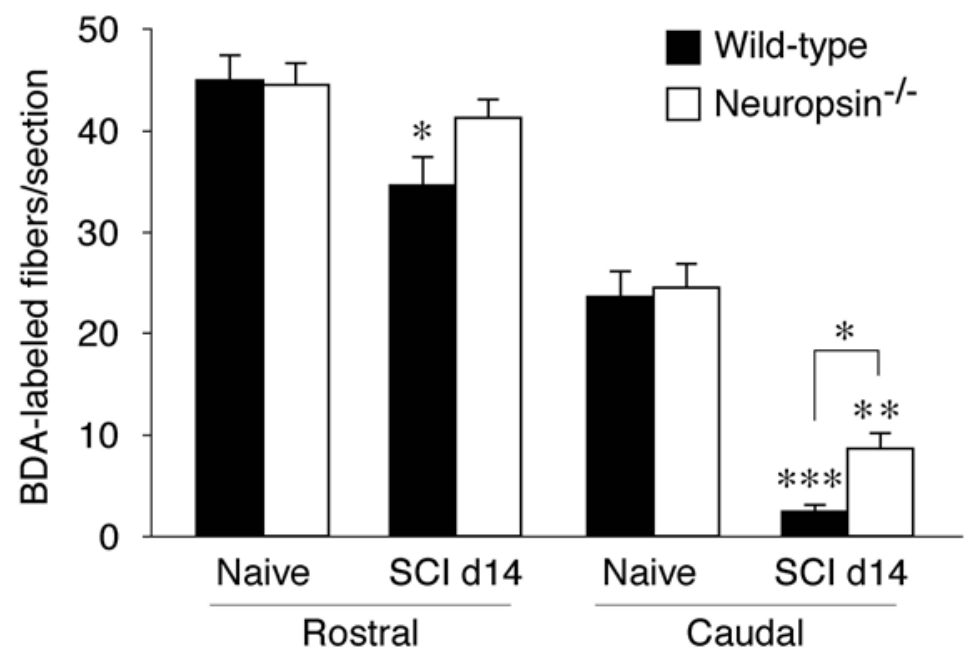

Figure 7 

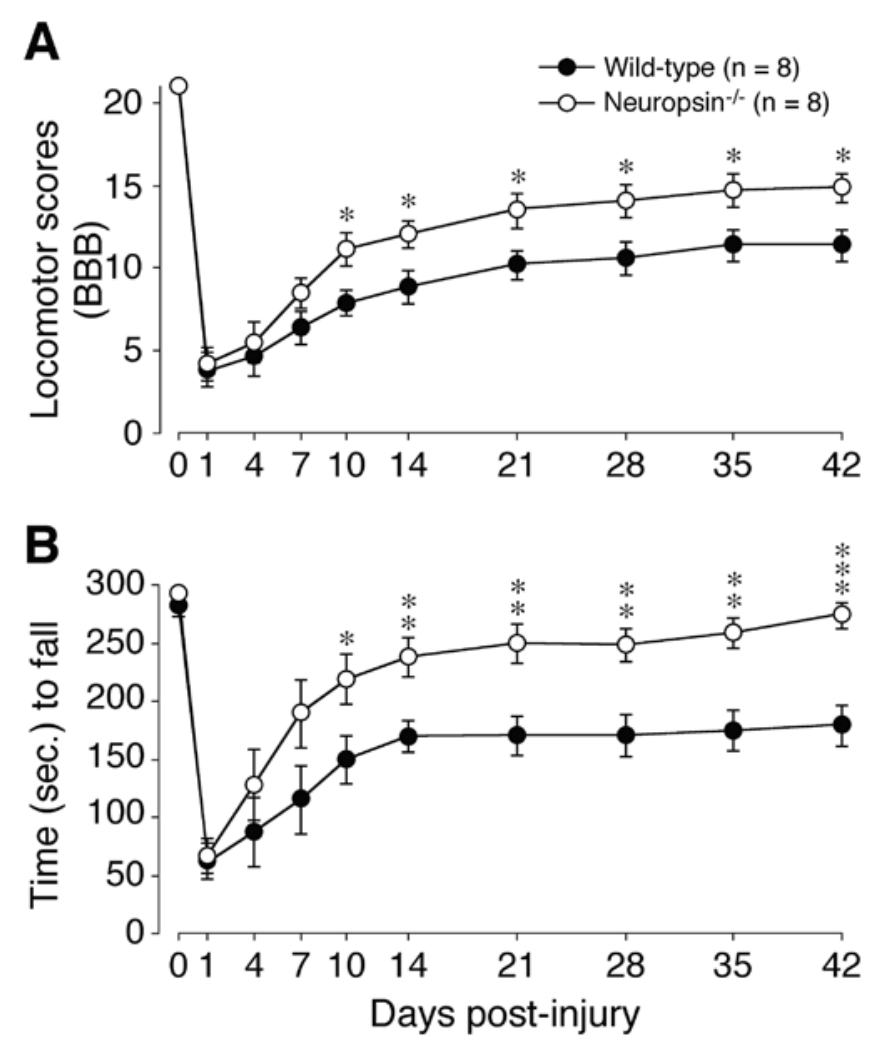

Figure 8 